\title{
E-cadherin expression in primary carcinomas of the breast and its distant metastases
}

\author{
Paul J Kowalski ${ }^{1}$, Mark A Rubin ${ }^{2}$ and Celina G Kleer ${ }^{1}$ \\ ${ }^{1}$ Department of Pathology and Comprehensive Cancer Center, University of Michigan Medical School, Ann Arbor, Michigan, USA \\ 2Department of Pathology, Brigham and Women's Hospital, Harvard Medical School, Boston, Massachusetts, USA \\ Correspondence: Celina G Kleer (e-mail: kleer@umich.edu)
}

Received: 1 Jul 2003 Revisions requested: 14 Aug 2003 Revisions received: 18 Aug 2003 Accepted: 22 Aug 2003 Published: 26 Sep 2003

Breast Cancer Res 2003, 5:R217-R222 (DOI 10.1186/bcr651)

(c) 2003 Kowalski et al., licensee BioMed Central Ltd (Print ISSN 1465-5411; Online ISSN 1465-542X). This is an Open Access article: verbatim copying and redistribution of this article are permitted in all media for any purpose, provided this notice is preserved along with the article's original URL.

\begin{abstract}
Introduction Aberrant expression of E-cadherin has been associated with the development of metastases in patients with breast cancer. Even though the expression of E-cadherin has been studied in primary breast tumors, little is known about its expression at the distant metastatic sites. We investigate the relationship between $\mathrm{E}$-cadherin expression in primary breast carcinoma and their distant, non-nodal metastases.
\end{abstract}

Methods Immunohistochemical analysis of E-cadherin was performed in tissues from 30 patients with primary invasive breast carcinoma and their distant metastases. E-cadherin expression was evaluated as normal or aberrant (decreased when compared with normal internal positive controls, or absent).

Results Twenty-two (73\%) invasive carcinomas were ductal, and eight $(27 \%)$ were lobular. Of the primary invasive ductal carcinomas, 55\% (12/22) had normal E-cadherin expression and $45 \%(10 / 22)$ had aberrant expression. All of the metastases expressed E-cadherin with the same intensity as (12 tumors) or with stronger intensity than (10 tumors) the corresponding primaries. Of the invasive lobular carcinomas, one of eight $(12 \%)$ primary carcinomas and none of the metastases expressed E-cadherin in the cell membranes, but they accumulated the protein in the cytoplasm.

Conclusion Aberrant E-cadherin expression is frequent in invasive ductal carcinomas that progress to develop distant metastases. Distant metastases consistently express E-cadherin, often more strongly than the primary tumor. Invasive lobular carcinomas have a different pattern of $\mathrm{E}$-cadherin expression, suggesting a different role for E-cadherin in this form of breast carcinoma.

Keywords: breast cancer, e-cadherin, metastases

\section{Introduction}

Tumor invasion with subsequent metastases is the major cause of morbidity and mortality in patients with cancer. For patients with breast cancer, the development of metastases is the most important prognostic factor, as almost all patients with distant metastasis succumb to the disease [1-3].

Numerous studies have linked aberrant expression of $\mathrm{E}$-cadherin with the development of metastases in breast cancer and other cancers. E-cadherin is a transmembrane glycoprotein that mediates calcium-dependent intercellular adhesion and is specifically involved in epithelial cell-tocell adhesion [4-6]. The E-cadherin gene, located on chromosome $16 q 22.1$, is an important regulator of morphogenesis $[7,8]$. In cancer, decreased E-cadherin expression is one of the alterations that characterizes the invasive phenotype, and the data support its role as a tumor suppressor gene [9-12]. Studies have shown that aberrant E-cadherin expression is associated with the acquisition of invasiveness and more advanced tumor stage for many cancers including lung cancer [13], prostate cancer [14,15], gastric cancer [16], colorectal carcinoma [17], and breast cancer [18-20].

Normal ductal epithelial cells in the mammary gland strongly express E-cadherin protein in the cytoplasmic membrane $[21,22]$. Some studies in breast cancer have 
demonstrated that aberrant E-cadherin expression is associated with high-grade, estrogen receptor (ER)-negative, and metastatic breast carcinomas, whereas other studies have failed to confirm these findings [22-24]. In the present article, we set out to determine and compare the expression patterns of E-cadherin in primary breast carcinomas and their distant, non-nodal metastases.

\section{Materials and methods Patient selection}

Thirty patients with breast cancer who developed distant metastases were identified using a computerized database. Breast tissues from the primary carcinoma and the corresponding distant, non-nodal metastases were retrieved from the Surgical Pathology files in our institution, with Institutional Review Board approval.

We identified 30 cases of primary invasive breast carcinomas and 32 cases of distant metastases (two patients each had two metastatic sites). Hematoxylin and eosin stained slides were available for review in all cases. Primary invasive carcinomas were measured microscopically, and were classified as invasive ductal carcinoma, invasive lobular carcinoma or other special types according to well-accepted criteria $[25,26]$. A histologic grade was assigned to each primary invasive carcinoma [27].

\section{Immunohistochemistry}

E-cadherin protein expression was studied by immunohistochemistry using specific monoclonal antibodies against E-cadherin (HEC-D10; Zymed Laboratories, San Francisco, CA, USA). For assessment of ER, progesterone receptor (PR) and HER2/neu expression, specific monoclonal antibodies for ER (Ventana Medical Systems, Tucson, AZ, USA), PR (DAKO, Carpinteria, CA, USA), and HER2/neu (Herceptest; DAKO) were used following the manufacturers' recommended dilutions.

Immunohistochemistry was performed using an automated immunostainer (Biotek Techmate 500; Ventana Medical Systems) as described previously [28]. Briefly, $5 \mu \mathrm{m}$-thick sections were cut onto glass slides from formalin-fixed, paraffin tissue blocks. Sections were deparaffinized and were microwaved (1000W Model \#MTC1080-2A; Frigidaire, Dublin, OH, USA) in a pressure cooker (Nordic Ware, Minneapolis, MN, USA) with 1 I of $10 \mathrm{mM}$ citrate buffer ( $\mathrm{pH}$ 6.0). The sections were subsequently cooled with the lid on for an additional $10 \mathrm{~min}$. After removing the lid, the entire pressure cooker was filled with cold, running tap water for 2-3 min or until the slides were cool. At $36^{\circ} \mathrm{C}$, the stainer sequentially added an inhibitor of endogenous peroxidase, the primary antibodies (32 min), a biotinylated secondary antibody, an avidin-biotin complex with horseradish peroxidase, 3,3'-diaminobenzidine tetrahydrochloride, and copper enhancer. The slides

\section{Interpretation of immunohistochemical analysis}

E-cadherin expression was interpreted as either normal (strong) or aberrant (reduced or absent) [29]. Internal positive controls, such as benign breast lobules and ducts, were present in most cases. Aberrant staining was defined as either negative staining or $<70 \%$ membranous staining of the population of cells examined. Normal staining was defined as $\geq 70 \%$ membranous staining of the cancer cells [29]. The ER and PR were considered positive when $>10 \%$ of the tumor cell nuclei were stained. For HER-2/neu, the strength of the membranous staining was recorded as $0,1+$ to $3+$, and a sample was considered positive when $10 \%$ or more neoplastic cells had a staining intensity of $\geq 2+[30]$.

\section{Statistical analysis}

Differences in percentages of E-cadherin-positive cases between the primary and metastatic groups were tested for statistical significance using Fisher's exact test. $P<0.05$ was considered significant. A two-sample $t$ test was also performed to compare the size, the ER, PR and HER-2/neu status, and the E-cadherin expression.

\section{Results}

\section{Clinical and pathological features}

The patients' characteristics are presented in Table 1. All patients were female.

The median age at diagnosis of the primary invasive breast carcinoma was 53.9 years (range, $39-80$ years). All primary tumors were treated by surgical excision. Of the primary tumors, 22 were invasive ductal carcinomas and eight were invasive lobular carcinomas. Metastatic sites included the liver (six cases), the bone marrow (five cases), the skin (four cases), the lung (three cases), the femoral head (three cases), the pelvic girdle (two cases), the vertebrae (two cases), the brain (two cases), the colon (one case), the ovary (one case), the pericardium (one case), the abdominal wall (one case), and the contralateral breast (one case).

\section{E-cadherin expression in primary and distant metastases}

Normal breast epithelial cells were used as internal positive controls for E-cadherin staining in tissue sections. The glandular epithelium consistently demonstrated unequivocal and strong membranous staining localized at the cell borders. The nonepithelial components were negative for $\mathrm{E}$-cadherin protein expression. Of the invasive ductal carcinomas, 55\% (12/22) had normal E-cadherin expression and $45 \%(10 / 22)$ had aberrant E-cadherin protein expression. Of the distant metastases of ductal carcinomas, $70 \%(16 / 23)$ had normal E-cadherin expression and 30\% (7/23) had aberrant expression.

When we compared the staining intensity, all the metastatic cancer cells had E-cadherin expression equal to 
Table 1

\begin{tabular}{|c|c|}
\hline Number of patients & 30 \\
\hline Median age (range) (years) & $53.9(39-80)$ \\
\hline \multicolumn{2}{|c|}{ Pathologic stage at diagnosis $[n(\%)]$} \\
\hline Stage I & $3(10)$ \\
\hline Stage II & $13(43.3)$ \\
\hline Stage III & $6(20)$ \\
\hline Stage IV & $2(6.7)$ \\
\hline Tumor size (range) (cm) & $2.7(0.5-7)$ \\
\hline \multicolumn{2}{|l|}{ Histologic type [n (\%)] } \\
\hline Ductal & $22(73)$ \\
\hline Lobular & $8(27)$ \\
\hline \multicolumn{2}{|l|}{ Histologic grade $[n(\%)]$} \\
\hline Grade 1 & $6(20)$ \\
\hline Grade 2 & $17(57)$ \\
\hline Grade 3 & $7(23)$ \\
\hline \multicolumn{2}{|l|}{ Lymph node status $[n(\%)]$} \\
\hline Negative & $7(28)$ \\
\hline Positive & $18(72)$ \\
\hline \multicolumn{2}{|c|}{ Estrogen receptor status [ $n(\%)]$} \\
\hline Negative & $7(27)$ \\
\hline Positive & $19(73)$ \\
\hline \multicolumn{2}{|c|}{ Progesterone receptor status $[n(\%)]$} \\
\hline Negative & $9(36)$ \\
\hline Positive & $16(64)$ \\
\hline \multicolumn{2}{|c|}{ Median time to develop distant metastases (months) } \\
\hline Ductal & 33 \\
\hline Lobular & 74 \\
\hline
\end{tabular}

$(13 / 23)$ or stronger than $(10 / 23)$ the corresponding primary tumors. Figure 1 shows a primary invasive ductal carcinoma with aberrant E-cadherin expression that developed a metastasis to the iliac bone expressing normal levels of E-cadherin (or re-expression). Figure 2 shows examples of distant metastases of invasive ductal carcinomas with normal E-cadherin expression.
Figure 2

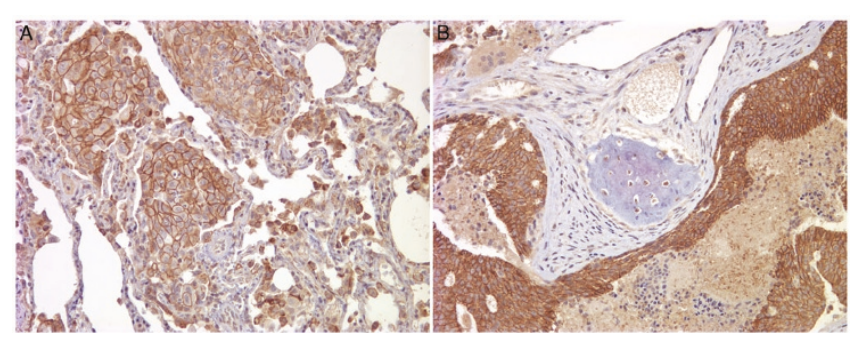

E-cadherin is expressed at normal levels at the metastatic foci. Distant metastases from two different primary invasive ductal carcinomas to (A) the lung and (B) the bone. Note the crisp membranous staining for E-cadherin, which is specific for the cancer cells. Fibroblasts and other stromal cells are negative. $200 \times$ magnification.

All invasive lobular carcinomas (eight cases) showed cytoplasmic staining and no protein in the cellular membrane (Fig. 3). Seventy-eight percent (7/9) of metastatic lobular carcinomas showed E-cadherin protein localized to the cytoplasm of the tumor cells. The other two metastatic foci of lobular carcinoma had normal E-cadherin expression (Table 2). No association was found between E-cadherin expression in primary invasive ductal carcinomas and the ER, PR and HER-2/neu status, the histologic grade, and the tumor size.

\section{Discussion}

The expression of E-cadherin in breast cancer metastases is largely unknown and, to our knowledge, there are no studies that specifically investigate the expression of $\mathrm{E}$-cadherin in primary breast carcinomas in relationship to their distant metastases. We found that aberrant E-cadherin expression is a common event in primary invasive ductal carcinomas that progress to develop distant metastases, as aberrant expression was found in $45 \%$ of these cases.

There is increasing evidence that cancer cells may re-express E-cadherin protein once they reach distant sites. We found that all the metastatic deposits from invasive ductal carcinomas expressed E-cadherin, and the

\section{Figure 1}

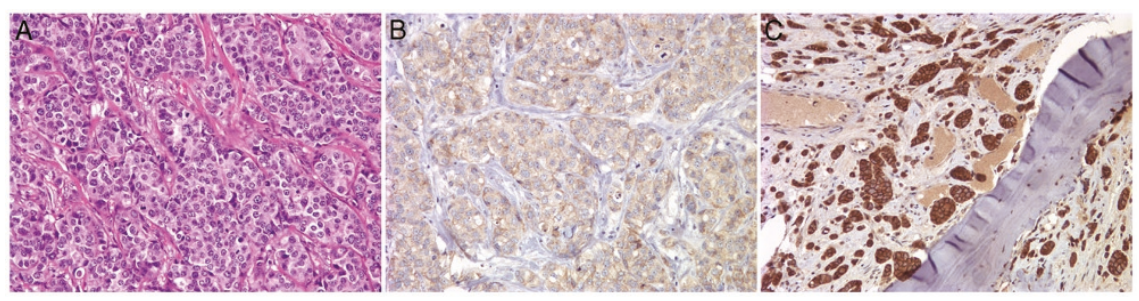

E-cadherin expression at the primary and distant metastatic sites. (A) and (B) Primary invasive ductal carcinoma with aberrant (reduced) E-cadherin expression. (C) This tumor metastasized 3 years later to the iliac bone. The metastatic carcinoma cells express normal levels of E-cadherin (reexpression). $200 \times$ magnification. 


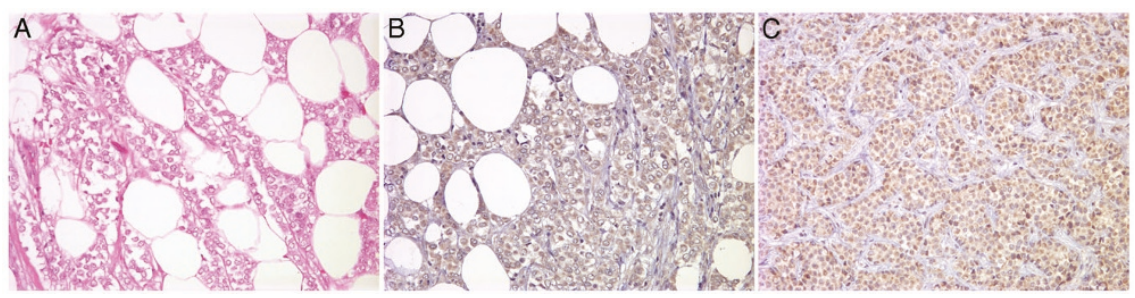

E-cadherin is accumulated in the cytoplasm of primary and metastatic lobular carcinomas of the breast. (A) and (B) Primary invasive lobular carcinoma invading fat. Notice the cellular discohesion and vacuolization typical of invasive lobular carcinomas. This tumor has cytoplasmic accumulation of E-cadherin. (C) Distant metastasis to the liver 8 years later exhibiting the pattern of E-cadherin expression as the primary tumor. $200 \times$ magnification.

Table 2

\begin{tabular}{|c|c|c|c|}
\hline Histologic type & Total cases & Aberrant & Normal \\
\hline \multicolumn{4}{|l|}{ Ductal carcinoma } \\
\hline Primary tumor & 22 & $10(45 \%)$ & $12(55 \%)$ \\
\hline Metastases & 23 & $7(30 \%)$ & $16(70 \%)$ \\
\hline \multicolumn{4}{|l|}{ Lobular carcinoma } \\
\hline Primary tumor & 8 & $8(100 \%)$ & 0 \\
\hline Metastases & 9 & $7(78 \%)$ & $2(12 \%)$ \\
\hline
\end{tabular}

degree of expression was either equal to or stronger than that of the primary tumor. By studying E-cadherin expression in nodal breast cancer metastases, Bukholm and colleagues found that 19 of 20 lymph node metastases strongly expressed E-cadherin protein [21]. The mechanism and biologic role of E-cadherin re-expression at the metastatic site has not been elucidated, although it appears that translational regulation and post-translational events are probable mechanisms of E-cadherin re-expression [31].

In order to metastasize, cancer cells must break away from the primary tumor, move into the surrounding stroma, intravasate into the circulation, extravasate, and successfully re-establish growth at other sites. It is possible that loss of E-cadherin is a transient phenomenon that allows malignant cells to invade vascular channels and tissues. We have previously demonstrated that intralymphatic breast cancer emboli strongly express E-cadherin protein, and we postulate that re-expression of E-cadherin occurs in the circulating tumor cells, enabling the cancer cells to form tumor emboli and to survive [28]. E-cadherin re-expression may also enable malignant cells to form a
The normal expression or re-expression of E-cadherin in cancer metastases appears to be similar in breast cancer and prostate cancer. Rubin and colleagues studied a large group of prostate cancers that included 77 distant metastases and detected normal E-cadherin expression in $90 \%$ of these cases [29].

In breast cancer, a relationship between E-cadherin expression and ER expression has been noted previously. ER-positive tumors have been demonstrated to express normal amounts of E-cadherin protein, and loss of ER and $\mathrm{E}$-cadherin genes has been linked to disease progression in invasive carcinomas of the breast. Nass and colleagues found an association between coincident methylation of $\mathrm{E}$-cadherin and the ER gene during breast cancer progression, probably not attributable to coincidence of methylation for the two genes [32]. In our study, however, we did not find an association between E-cadherin expression and the ER, PR or HER-2/neu status.

The role of E-cadherin in the pathogenesis and progression of invasive lobular carcinoma is intriguing. We found that all of the primary invasive lobular carcinomas and nearly all of the metastatic foci had accumulation of E-cadherin protein in the cytoplasm of the neoplastic cells, with no membranous staining. Several studies have demonstrated that E-cadherin is commonly downregulated in invasive lobular carcinomas [33-36]. Berx and colleagues found somatic mutations of the E-cadherin gene in $56 \%$ (27/48 cases) of invasive lobular carcinomas, and $90 \%$ of these tumors had allelic losses at the E-cadherin locus. No mutations were identified in 50 nonlobular breast cancers [34]. Sarrio and colleagues recently reported that promoter hypermethylation is another common mechanism of E-cadherin inactivation in invasive lobular carcinomas, occurring in $41 \%(19 / 46)$ of cases [36]. De Leeuw and colleagues reported that $84 \%$ (32/38) of invasive lobular carcinomas had completely absent membranous staining by immunohistochemistry, and $56 \%$ of these cases had staining in the cytoplasm of the cancer cells [33]. 
The clearly different pattern of E-cadherin expression in invasive ductal and lobular carcinomas suggests that this protein may play different roles in the development of each specific type of tumor. The absence of membranous E-cadherin expression in invasive lobular carcinomas may determine the morphologic features such as the characteristic cellular discohesion of the lobular carcinoma cells, as well as the distinct pattern of stromal invasion of invasive lobular carcinomas, typically as single cells or rows of cells.

In summary, the present study provides evidence that approximately one-half of the invasive ductal carcinomas that develop distant metastases have aberrant E-cadherin protein expression. E-cadherin is expressed or reexpressed at the distant metastatic foci of invasive ductal carcinomas, supporting the hypothesis that re-expression of E-cadherin may play a role in the establishment of the metastatic cells at distant sites. Invasive lobular carcinomas have a different pattern of E-cadherin expression both at the primary carcinoma and the metastatic sites, which suggests a different role for E-cadherin in this form of breast cancer.

\section{Conclusion}

In the present study we specifically determine the expression of E-cadherin protein in primary invasive carcinomas and their corresponding distant metastases. We conclude that E-cadherin is expressed at normal levels at the distant metastatic site regardless of the level of expression at the primary invasive ductal carcinoma. This observation may have biological implications, as re-expression of E-cadherin may allow malignant cells to form the metastatic deposits. Invasive lobular carcinomas have a different pattern of E-cadherin expression both in the primary tumor and at the metastatic site.

\section{Competing interests}

None declared.

\section{Acknowledgements}

This work was supported by DOD grant DAMD 17-02-1-0490 and DAMD 17-02-0491 (CGK), and by a grant from the John and Suzanne Munn Endowed Research Fund of the University of Michigan Comprehensive Cancer Center (CGK).

\section{References}

1. Haybittle JL, Blamey RW, Elston CW, Johnson J, Doyle PJ, Campbell FC, Nicholson RI, Griffiths K: A prognostic index in primary breast cancer. Br J Cancer 1982, 45:361-366.

2. Rosen PR, Groshen S, Saigo PE, Kinne DW, Hellman S: A longterm follow-up study of survival in stage I (T1NOMO) and stage II (T1N1M0) breast carcinoma. J Clin Oncol 1989, 7:355366.

3. Danforth DN, Lichter A, Lippman ME: The diagnosis of breast cancer. In Diagnosis and Management of Breast Cancer. Edited by Danforth Jr DN, Lichter A, Lippman ME (Eds). Philadelphia, PA: WB Saunders; 1988:50-94.

4. Gumbiner BM: Regulation of cadherin adhesive activity. J Cell Biol 2000, 148:399-404.
5. Deman JJ, Van Larebeke NA, Bruyneel EA, Bracke ME, Vermeulen SJ, Vennekens KM, Mareel MM: Removal of sialic acid from the surface of human MCF-7 mammary cancer cells abolishes Ecadherin-dependent cell-cell adhesion in an aggregation assay. In Vitro Cell Dev Biol Anim 1995, 31:633-639.

6. Shore EM, Nelson WJ: Biosynthesis of the cell adhesion molecule uvomorulin (E-cadherin) in Madin-Darby canine kidney epithelial cells. J Biol Chem 1991, 266:19672-19680.

7. Day ML, Zhao X, Vallorosi CJ, Putzi M, Powell CT, Lin C, Day KC: $\mathrm{E}$-cadherin mediates aggregation-dependent survival of prostate and mammary epithelial cells through the retinoblastoma cell cycle control pathway. J Biol Chem 1999, 274:96569664.

8. Peifer M: Beta-catenin as oncogene: the smoking gun. Science 1997, 275:1752-1753.

9. Gamallo C, Palacios J, Suarez A, Pizarro A, Navarro P, Quintanilla $\mathrm{M}$, Cano A: Correlation of E-cadherin expression with differentiation grade and histological type in breast carcinoma. Am J Pathol 1993, 142:987-993.

10. Frixen UH, Behrens J, Sachs M, Eberle G, Voss B, Warda A, Lochner D, Birchmeier W: E-cadherin-mediated cell-cell adhesion prevents invasiveness of human carcinoma cells. J Cell Biol 1991, 113:173-185.

11. Pierceall WE, Woodard AS, Morrow JS, Rimm D, Fearon ER: Frequent alterations in E-cadherin and alpha- and beta-catenin expression in human breast cancer cell lines. Oncogene 1995, 11:1319-1326.

12. Chen WC, Obrink B: Cell-cell contacts mediated by E-cadherin (uvomorulin) restrict invasive behavior of L-cells. J Cell Biol 1991, 114:319-327.

13. Shimoyama $Y$, Hirohashi S, Hirano S, Noguchi M, Shimosato $Y$, Takeichi M, Abe O: Cadherin cell-adhesion molecules in human epithelial tissues and carcinomas. Cancer Res 1989, 49:2128-2133.

14. Umbas R, Isaacs WB, Bringuier PP, Schaafsma HE, Karthaus HF, Oosterhof GO, Debruyne FM, Schalken JA: Decreased E-cadherin expression is associated with poor prognosis in patients with prostate cancer. Cancer Res 1994, 54:3929-3933.

15. Umbas R, Isaacs WB, Bringuier PP, Xue Y, Debruyne FM, Schalken JA: Relation between aberrant alpha-catenin expression and loss of E-cadherin function in prostate cancer. Int $J$ Cancer 1997, 74:374-377.

16. Mayer B, Johnson JP, Leitl F, Jauch KW, Heiss MM, Schildberg FW, Birchmeier W, Funke I: E-cadherin expression in primary and metastatic gastric cancer: down-regulation correlates with cellular dedifferentiation and glandular disintegration. Cancer Res 1993, 53:1690-1695.

17. Dorudi S, Hanby AM, Poulsom R, Northover J, Hart IR: Level of expression of E-cadherin mRNA in colorectal cancer correlates with clinical outcome. Br J Cancer 1995, 71:614-616.

18. Rasbridge SA, Gillett CE, Sampson SA, Walsh FS, Millis RR: Epithelial (E-) and placental (P-) cadherin cell adhesion molecule expression in breast carcinoma. J Pathol 1993, 169:245250.

19. Oka H, Shiozaki H, Kobayashi K, Inoue M, Tahara H, Kobayashi T, Takatsuka Y, Matsuyoshi N, Hirano S, Takeichi M: Expression of E-cadherin cell adhesion molecules in human breast cancer tissues and its relationship to metastasis. Cancer Res 1993, 53:1696-1701.

20. Palacios J, Benito N, Pizarro A, Suarez A, Espada J, Cano A, Gamallo C: Anomalous expression of P-cadherin in breast carcinoma. Correlation with E-cadherin expression and pathological features. Am J Pathol 1995, 146:605-612.

21. Bukholm IK, Nesland JM, Borresen-Dale AL: Re-expression of Ecadherin, alpha-catenin and beta-catenin, but not of gammacatenin, in metastatic tissue from breast cancer patients [see comments]. J Pathol 2000, 190:15-19.

22. Bukholm IK, Nesland JM, Karesen R, Jacobsen U, Borresen-Dale $\mathrm{AL}$ : E-cadherin and alpha-, beta-, and gamma-catenin protein expression in relation to metastasis in human breast carcinoma. J Pathol 1998, 185:262-266.

23. Jones JL, Royall JE, Walker RA: E-cadherin relates to EGFR expression and lymph node metastasis in primary breast carcinoma. Br J Cancer 1996, 74:1237-1241.

24. Moll R, Mitze M, Frixen UH, Birchmeier W: Differential loss of Ecadherin expression in infiltrating ductal and lobular breast carcinomas. Am J Pathol 1993, 143:1731-1742. 
25. Rosen PP, Oberman HA: Tumors of the Mammary Gland. Atlas of Tumor Pathology. Washington, DC: Armed Forces Institute of Pathology; 1993.

26. Tavassoli F: General considerations in breast pathology. In Breast Pathology. Edited by Tavassoli F. Connecticut: Appelton \& Lange, 1999:27-74.

27. Elston CW, Ellis IO: Pathological prognostic factors in breast cancer. I. The value of histological grade in breast cancer: experience from a large study with long-term follow-up. Histopathology 1991, 19:403-410.

28. Kleer CG, van Golen KL, Braun T, Merajver SD: Persistent Ecadherin expression in inflammatory breast cancer. Mod Pathol 2001, 14:458-464.

29. Rubin MA, Mucci NR, Figurski J, Fecko A, Pienta KJ, Day ML: Ecadherin expression in prostate cancer: a broad survey using high-density tissue microarray technology. Hum Pathol 2001, 32:690-697.

30. Seidman AD, Fornier MN, Esteva FJ, Tan L, Kaptain S, Bach A, Panageas KS, Arroyo C, Valero V, Currie V, Gilewski T, Theodoulou M, Moynahan ME, Moasser M, Sklarin N, Dickler M, D'Andrea G, Cristofanilli M, Rivera E, Hortobagyi GN, Norton L, Hudis CA: Weekly trastuzumab and paclitaxel therapy for metastatic breast cancer with analysis of efficacy by HER2 immunophenotype and gene amplification. J Clin Oncol 2001, 19:2587-2595

31. Rashid MG, Sanda MG, Vallorosi CJ, Rios-Doria J, Rubin MA, Day $\mathrm{ML}$ : Posttranslational truncation and inactivation of human $\mathrm{E}$ cadherin distinguishes prostate cancer from matched normal prostate. Cancer Res 2001, 61:489-492.

32. Nass SJ, Herman JG, Gabrielson E, Iversen PW, Parl FF, Davidson NE, Graff JR: Aberrant methylation of the estrogen receptor and E-cadherin $5^{\prime} \mathrm{CpG}$ islands increases with malignant progression in human breast cancer. Cancer Res 2000, 60: 4346-4348.

33. De Leeuw WJ, Berx G, Vos CB, Peterse JL, Van de Vijver MJ, Litvinov S, Van Roy F, Cornelisse CJ, Cleton-Jansen AM: Simultaneous loss of E-cadherin and catenins in invasive lobular breast cancer and lobular carcinoma in situ. J Pathol 1997, 183:404-411.

34. Berx G, Cleton-Jansen AM, Nollet F, de Leeuw WJ, van de Vijver $M$, Cornelisse $C$, van Roy $F$ : E-cadherin is a tumour/invasion suppressor gene mutated in human lobular breast cancers. Embo J 1995, 14:6107-6115.

35. Berx G, Cleton-Jansen AM, Strumane K, de Leeuw WJ, Nollet F, van Roy F, Cornelisse C: E-cadherin is inactivated in a majority of invasive human lobular breast cancers by truncation mutations throughout its extracellular domain. Oncogene 1996, 13: 1919-1925.

36. Sarrio D, Moreno-Bueno G, Hardisson D, Sanchez-Estevez C, Guo M, Herman JG, Gamallo C, Esteller M, Palacios J: Epigenetic and genetic alterations of APC and CDH1 genes in lobular breast cancer: relationships with abnormal E-cadherin and catenin expression and microsatellite instability. Int J Cancer 2003, 106:208-215.

\section{Correspondence}

Celina G Kleer, MD, Department of Pathology, 2G332 University Hospital, 1500 East Medical Center Drive, Ann Arbor, Ml 48109-0054, USA. Tel: +1 734936 6775; fax: +1 734763 4095; e-mail: kleer@umich.edu 